\title{
KTSP TRANSITION TOWARDS 2013 CURRICULUM AT JUNIOR HIGH SCHOOL OF TAMAN DEWASA IBU PAWIYATAN TAMANSISWA, YOGYAKARTA
}

\author{
Atik Nidaul Husna US ${ }^{a^{*}}$, Wiwik Wijayanti ${ }^{b}$ \\ ${ }^{a * b}$ Educational Management, \\ Yogyakarta State University \\ Daerah Istimewa Yogyakarta, Indonesia. ${ }^{\left.a^{*}\right)}$ Nidaashakina9@ gmail.com, b)wiwik_wijayanti@uny.ac.id
}

\begin{abstract}
All of schools policy will surely reap different reactions. 2013 curriculum which was allegedly reformer of KTSP is now a big question about the success of its implementation. This study aims to describe the process of implementing the curriculum 2013 transition at Junior High School of Taman Dewasa Ibu Pawiyatan Tamansiswa, Yogyakarta. The method of this study was qualitative with the type of case study approach. The results of this study indicate that (1). Curriculum planning involves all relevant stakeholders, including: the principal, deputy head of curriculum, deputy head of students' affairs, deputy head of facilities and infrastructure, teacher teams and school committees. (2). The implementation of the curriculum was carried out in stages. Starting with applying the 2013 curriculum in grades 7 and 8, meanwhile grade 9 still uses the KTSP. (3). Evaluation of curriculum has two categories of assessment that come from internal and external schools. The results describe that 2013 curriculum can be implemented gradually well. The conclusion is transition from KTSP to 2013 curriculum gradually. In the near future, the school will implement the 2013 curriculum thoroughly in every class without leaving the school's specificity with the values of art, culture and character.
\end{abstract}

Keywords: curriculum transition, curriculum management, KTSP, and 2013 curriculum.

Received: 20 Jan 2020 - Revised: 28 Feb 2020 - Accepted 25 March 2020 - Available online 30 June 2020

\section{INTRODUCTION}

The transition period is a transition from the old state to the new direction. In the transition period will always be accompanied by pros and cons. Likewise with the curriculum transition, to date applying the 2013 curriculum as a reformer of the Education Unit Level Curriculum (KTSP) is still controversial. Basically, the curriculum changes were made by the government with a view to making improvements to the education system. In the history of Indonesian education, at least 10 types of curriculum have been presented. The ten types of curriculum, starting from the era after independence until the curriculum

currently in force, consists of: first, the 1947 lesson plan; second, the 1952 curriculum; three, 1964 curriculum; Fourth, 1968 curriculum; range, curriculum 1975/1976; sixth, the 1984 curriculum; seventh, 1994 curriculum; eighth, curriculum 2002 and 2004; ninth, Education Unit Level Curriculum (KTSP) 2006; and tenth, 2013 curriculum. In other words, curriculum changes in Indonesia can be done for the first time and is something that makes sense. Curriculum changes occur as impacts and implications of changes in the political system, socio-cultural, economic and development of science and technology from time to time (Hidayat, 2013).

Curriculum change in the education system in Indonesia is no longer something surprising, given the rationalization that is always touted that curriculum changes are made to answer and adjust the challenges of an ever-changing era that cannot be prevented and to prepare 
students who are able to compete in the future with all scientific advancements. The problems faced by the Indonesian nation are increasingly complex offering students such as student brawl, gambling, studying illegal drugs, drugs, corruption, collusion and nepotism (KKN), plagiarism, leakage and various internal fraud tests to change the basic education needs of the system. Another factor, namely various problems and challenges of the future that are increasingly complex. Various challenges in the future and the free market, environmental problems, rapid advances in information technology, the convergence of science and technology, knowledge-based economics, building creative and cultural industries, changing the strength of the world economy, the influence and impact of science, quality, investment and transformation in the education sector, as well as TIMSS and PISA material that must be attended by students (Mulyasa, 2013). All of them encourage the development of a new curriculum. Curriculum 2013, which is collected accommodative, solutive and anticipatory to various problems, needs, and challenges in society both now and in the future. Knowledge and technology that continues to grow. Changes to the curriculum launched, of course, have passed the appropriate stages such as the stage of problem formulation, the stage of agenda setting, the stage of policy formulation, the stage of policy legitimacy, the stage of policy implementation, and the stage of policy evaluation (Kurniasih \& Sani, 2014). In the National Education Standards (SNP article 1, paragraph 15) stated that the KTSP is an operational curriculum developed and implemented by each educational unit with due regard to and based on competency standards and basic competencies developed based on the Law Invite No. 20 of 2003 concerning the National Education System (SPN article 2, paragraph 1). The KTSP is a refinement of the 2004 curriculum $(\mathrm{KBK})$ is an operational curriculum compiled and implemented by each education unit or school. Related to the preparation of this KTSP, BSNP has made guidelines for the preparation of KTSP. This guide is expected to become a reference for elementary / MI /
SDLB, SMP / MTs / SMPLB, SMA / MA / SMALB, and SMAK / MAK education units in the preparation and development of curriculum that will be implemented at the level of the relevant education units (Hakim, 2014).

Over time the implementation of KTSP in each education unit is deemed necessary to be revised. The reason is, since KTSP was implemented in 2006 there have been basic problems that need to be taken seriously by the government. In the process of learning the implementation of KTSP in its context to develop the activities and creativity of students, through interaction and learning experiences. However, there are still many learning activities carried out which actually hinder the activity and creativity of students. Based on these concerns, the government designed a new curriculum, the 2013 curriculum. The 2013 curriculum is a competency based curriculum designed to anticipate 21 st century competency needs. The 2013 curriculum aims to encourage students or students to be able to better observe, ask, reason, and communicating, (presenting) what they get or know after receiving the subject matter (Pawero, 2018). (Machali, 2014) added that the 2013 curriculum was a form of development and completion of the KTSP curriculum in 2006 where several problems were encountered in its implementation, namely: 1) The curriculum content was too dense aimed at the number of subjects and the amount of material was too broad and the level of difficulty beyond the level of development of the child's age, 2) Not yet fully competencybased in accordance with the demands of the functions and objectives of national education, 3) Competencies have not described holistically the attitudes, skills and knowledge domains, 4) Several competencies needed with the development needs such as: education character, active learning methodology, soft skills and hard skills balance, entrepreneurship, not yet accommodated in the KTSP curriculum, 5) Curriculum has not been sensitive and responsive to social changes that occur at the local, national, or global level, 6) Process standards learning has not yet described the meaning of learning detailed so 
as to open up opportunities for diverse interpretations and lead to teacher-centered learning, 7) Assessment standards have not led to competency-based assessments (processes and results) and have not explicitly demanded periodic remediation, and 8) KTSP requires documents detail so as not to cause multiple interpretations.

According to (Uran, 2018) Weakness of KTSP as follows: 1) Lack of books and learning resources, 2) Inappropriate time allocation, 3) Limited supporting facilities and infrastructure, 4) Lack of human resources , 5) Less than nonacademic learning outcomes (students), 6) Teachers are more active than students in the learning process. While the 2013 curriculum exertions given: 1) Published syllabus and translating books for teachers, 2) Ease in preparing lesson plans, 3) Students as learning centers (student centers), and 4) Shifting the creativity of teachers and students. Not much different according (Trisnawati, 2016) explain some of the shortcomings of the KTSP such as: 1) Adding the expected human resources can describe KTSP on the number of existing education schools and the lack of quality teachers and schools, 2) More precisely supporting facilities and infrastructure as a completion of KTSP implementation, 3) Approved KTSP implementation Progress in learning will result in increased teacher funding, 4) There are still many teachers who do not understand KTSP in the field. Following are the strengths of the 2013 curriculum, 1) Students are required to be active, creative and innovative in every problem solving they face at school, 2) Determination values for students are not only obtained from exam scores but also from values of politeness, religion, practice, attitudes and etc. 3) Character education and character education which have been integrated into all study programs.

From the description above, the 2013 curriculum is a breath of fresh air to replace or renew the KTSP system. (Machali, 2014) explained that the 2013 curriculum change was a form of development and improvement of the previous curriculum. The 2013 curriculum focuses on improving the mindset, strengthening curriculum management, deepening and extending the material, strengthening the learning process, and adjusting the learning load in order to ensure a match between what is desired and what is produced. On this basis, the improvement and implementation of the 2013 curriculum is believed to be a strategic step in preparing and facing the challenges of globalization and the future demands of Indonesian society. In this framework, the 2013 curriculum emphasizes the adjusted or adaptive function, which is the 2013 curriculum capable of directing its students to be able to adjust to the environment, both the physical environment and social environment that continues to experience changes. The 2013 curriculum integrates three domains of competence, namely: attitudes, knowledge, and skills which in their implementation are included in KI-1 (spiritual attitude), KI-2 (social attitude), KI-3 (knowledge), CC-4 (skills).

On the other hand, in the transition from KTSP to the 2013 curriculum in the education currently reaps various sloping perceptions that cannot be avoided, starting from questioning the maturation of the 2013 curriculum that has been prepared to school readiness in its application. Therefore, to better know about the process of transition implementing the KTSP towards the 2013 Curriculum that occurs entirely in the field, the researcher wants to see the process of implementing the KTSP towards the 2013 curriculum which is carried out in 2013. Junior High School of Taman Dewasa Ibu Pawiyatan Tamansiswa, Yogyakarta. Based on the background of the problem described above, the writer can then identify the problems that appear as follows: 1) KTSP has not been successfully implemented in accordance with the understanding of the actual KTSP. 2) Teacher performance has not been able to maximize the concept of KTSP in its preparation and practice in the field. 3) KTSP allegedly failed to develop students' activities and creativity. 4) The process of implementing the KTSP transition towards the 2013 curriculum seems rushed. 5) Sosialisation 
about Kurikulum 2013 is considered lacking. 6) The level of school readiness and teacher understanding of the essence of the 2013 curriculum is still low. To avoid widening the problem to be investigated, the problem is limited to the process of implementing the KTSP transition to the 2013 Curriculum. Based on the predetermined problem limitation, the research problem can be formulated as follows: 1) How is the plan of the 2013 curriculum at Junior High School of Taman Dewasa Ibu Pawiyatan Tamansiswa, Yogyakarta? 2) How is the implementation of the 2013 curriculum at Junior High School of Taman Dewasa Ibu Pawiyatan Tamansiswa, Yogyakarta? 3) How is the evaluation of the 2013 curriculum at Junior High School of Taman Dewasa Ibu Pawiyatan Tamansiswa, Yogyakarta? Based on the predetermined problem formulation, the purpose of this study is 1) To describe the plan of 2013 curriculum at Junior High School of Taman Dewasa Ibu Pawiyatan Tamansiswa, Yogyakarta? 2) To describe the implementation of 2013 curriculum at Junior High School of Taman Dewasa Ibu Pawiyatan Tamansiswa, Yogyakarta? 3) To describe the evaluation of 2013 curriculum at Junior High School of Taman Dewasa Ibu Pawiyatan Tamansiswa, Yogyakarta?

Question of Research

The Question:

1. How is the plan of the 2013 curriculum at Junior High School of Taman Dewasa Ibu Pawiyatan Tamansiswa, Yogyakarta?

2. How is the implementation of the 2013 curriculum at Junior High School of Taman Dewasa Ibu Pawiyatan Tamansiswa, Yogyakarta?

3. How is the evaluation of the 2013 curriculum at Junior High School of Taman Dewasa Ibu Pawiyatan Tamansiswa, Yogyakarta?

\section{METHODS}

This research uses a qualitative approach to the type of case study. Qualitative approach according to (Cresswell, 2015) is an approach to exploring problems and developing a detailed understanding of central phenomena.

The subjects in this study were all related the KTSP transition to the 2013 curriculum at Junior High School of Taman Dewasa Ibu Pawiyatan Tamansiswa including principals, deputy head curriculum, deputy head students, teachers, students and the facilities and infrastructure section. The research settings address Jl. Taman Siswa No. 31, Wirogunan, Kec. Mergangsan, Yogyakarta City, Special Region of Yogyakarta.

The research instrument was carried out using tools such as interview guidelines, recording devices, cameras, and field notes. While the data collection techniques used in this study were observation, interviews, and documentation. Observations were made to determine the conditions directly in the field. Interviews were conducted to explore in depth information about how to transition from KTSP towards the 2013 curriculum. Documentation was used to look at the real picture in the field related the KTSP transition to 2013 curriculum at Junior High School of Taman Dewasa Ibu Pawiyatan Tamansiswa, Yogyakarta?

The validity of the data in this qualitative study includes the test of credibility, transferability, dependability, and confirmability (Sugiyono, 2015). The details of the stages are as follows:

1. Credibility is one measure of the truth of data collected and illustrates the concept of researchers with concepts obtained from informants or informants. This stage is carried out by activities:

a. Triangulation. This activity is done by researchers as a correction of the correctness of the data by comparing data obtained from other sources, such as speakers who are considered competent. To achieve the credibility of the data in this study, one triangulation technique is used, namely source triangulation.

b. Member check. This activity was carried out to conclude together with each resource after 


\section{Atik Nidaul Husna US, et al. /Journal of Educational Administration Research and Review / \\ Vol. 4 No. 1 June 2020}

the researcher conducted an interview. This is done in order to avoid misperceptions between researchers and data sources or informants.

2. Transferability. This activity is also called internal validation. The results of this study may be used elsewhere.

3. Dependability. Is a way to maintain the validity of the data by conducting an audit of the entire research process. The trick is carried out by an independent auditor, or supervisor to audit the overall activities of researchers in conducting research.

4. Confirmability. Activities at this stage relate to the objectivity of the results of research that researchers do. The implementation is carried out by means of the respondent being asked to re-read the results of the interview data obtained whether it is in accordance with what the respondent said. Then the respondent was asked to provide a checklist or signature stating that the respondent agreed with the interview data that was transcribed by the researcher.

Data analysis by the researcher is by means of existing data which are analyzed based on an interactive analysis model with four important components, including data collection, data condensation, data presentation, and drawing conclusions or verification. These four components interact with each other and form a researcher's data analysis cycle (Miles, Huberman, \& Saldana, 2014).

\section{Data collection}

Data collection is done by researchers to record all data objectively and as is in accordance with the results of observations and interviews conducted in the field.

\section{Data condensation}

Data condensation was carried out by researchers to select the main things that fit the focus of the study. Data condensation is used by researchers to group, direct, and select data obtained by researchers in the form of interviews, observations, and documentation from informants.

\section{Presentation of data}

Presentation of the data is done by researchers to compile a set of information that allows for the withdrawal of conclusions.

\section{Drawing conclusions or verification}

After presenting the data, a conclusion is drawn or verified. From these data the researcher can draw conclusions and verify decisions by analyzing the factual findings in the field.

\section{RESULTS AND DISCUSSION}

\section{A. Results}

Junior High School of Taman Dewasa Ibu Pawiyatan Tamansiswa, Yogyakarta at Jalan Tamansiswa $25 \mathrm{~F}$, Wirogunan, Mergangsan District, Yogyakarta City Province D.I. Yogyakarta. The interview focused on the process of implementing the 2013 curriculum transition that was applied. There are three stages of core questions including: planning, implementing, and evaluating the 2013 curriculum. As (Lazwardi, 2017) said, curriculum management is an activity to facilitate the achievement of teaching objectives which include planning, implementation and evaluation (evaluation) to improve the quality of interaction learn how to teach.

Curriculum planning involves all relevant stakeholders, including: the principal, deputy head of curriculum, deputy head of students' affairs, deputy head of facilities and infrastructure, teacher teams and school committees. In the transition of 2013 curriculum of Junior High School of Taman Dewasa Ibu Pawiyatan Tamansiswa all aspects are considered in order to get conformity with the vision and mission of the school without eliminating the values that are characteristic of Junior High School of Taman Dewasa Ibu 
Pawiyatan Tamansiswa such as emphasizing the arts and culture and character. The relevance of curriculum planning of Junior High School of Taman Dewasa Ibu Pawiyatan Tamansiswa is done in such a way through semester programs and annual programs and it is not uncommon for schools to invite speakers from outside the school who are competent in their fields in the context of 2013 curriculum deepening, at least the school supervisors with to do workshops, seminars and training so that the curriculum planning of 2013 curriculum can to be implemented well.

The second core discussion is regarding curriculum implementation. The implementation of the curriculum in Junior High School of Taman Dewasa Ibu Pawiyatan Tamansiswa is done in stages by applying the two existing curriculum, namely the 2013 curriculum intended for grades 7 and 8, while the 2006 curriculum or KTSP is intended for grade 9 . The process of implementing the 2013 curriculum can be said to be going well and can meet the conditions specified as contained in curriculum planning.

In the process of implementing the 2013 curriculum is the school principal, teachers and all stakeholders work together well in carrying out their respective duties. The principal performs all administrative tasks and strives to meet the needs of teachers in carrying out the 2013 curriculum while the teacher measures the needs and difficulties experienced by students in the process of implementing the 2013 curriculum. The existence of meetings scheduled through the school calendar becomes a school tool to see the extent to which the 2013 curriculum can be applied accordingly with existing planning. The teacher reports all the 2013 curriculum processes that are undertaken in class and reports if there are students who have difficulty following the 2013 curriculum so that the principal can immediately see any progress in the 2013 curriculum implementation process and provide the best solution if there are students who have difficulty following the 2013 curriculum. According to (Hamalik, 2010) states that the implementation of the curriculum is divided into two levels, namely the application of the school level curriculum that is carried out by the principal and the class level is carried out by the teacher. Although there is a difference between the work of principals and the work of teachers in implementing the curriculum, they must work together and have one goal, namely the success of curriculum implementation.

School policies undertaken by school principals to support teachers in implementing the 2013 curriculum through socialization of the 2013 curriculum itself, one of which is by holding workshops, seminars and training that can support the curriculum implementation process in accordance with what has been designed in curriculum planning. Where speakers are also required at least school supervisors who are usually conducted at the beginning of the learning year around early June or other resource persons who are competent in their fields. So that there are no obstacles that still worry about the implementation of the curriculum both in the learning process in the classroom and outside the classroom such as how the curriculum is implemented, what administration must be met, and so on, including minimizing the difficulties of students in the implementation of the curriculum. (Wangid \& Dkk., 2018) explained that the socialization and training of the 2013 curriculum for teachers as implementers in the field became an important and mandatory law, bearing in mind the teacher as the main motor that determined the successful implementation of the 2013 curriculum.

The last discussion regarding curriculum evaluation. The 2013 curriculum evaluation at in Junior High School of Taman Dewasa Ibu Pawiyatan Tamansiswa has two evaluation categories which are internal and external to the school. Evaluations originating from internal schools include the principal, deputy head of curriculum, deputy head of students' affairs, deputy head of facilities and infrastructure, and teacher teams. While 
evaluations originating from external schools are school supervisors, the community, and school committees. The evaluation is carried out in the semester consisting of midterm and final semester with a school calendar tool that has been coordinated and mutually agreed upon and outlined in detail for its implementation. While for grade 9 there is a Material Deepening Test (MDT) as a student evaluation material in mastering the material that has been studied. This test is a school facility that occurs 2 times in 1 year. The 2013 curriculum transition evaluation did not have major difficulties. Teacher constraints at least there are difficulties in managing the class. However, this problem can be overcome by the collaboration between teachers in solving this problem. So the 2013 curriculum can be run as it should.

\section{B. Discussion}

Curriculum in a broad sense is a concept that refers to the prevailing education system. While in the strict sense means the unity of several subjects, one subject, a group of scientific groups, a learning plan program, and so on, which explains the plan for a series of learning activities (Answar, 2014). In 2012 the community especially in the world of education was appalled by the Government through the Ministry of Education and Culture (Kemendikbud) who developed and conducted a public test of the 2013 curriculum, precisely in 2013 the government officially adopted and developed the 2013 curriculum as a refinement of the previous curriculum.

According to (Prastowo, 2018) curriculum change in the context of education is a necessity. Because education cannot be alienated from the social, cultural, and community context that surrounds it. (Tilaar, 2012) added that the education curriculum always adapts to the development of the times around it. If the political, social, cultural, economic, and scientific context of society has changed, the educational curriculum must change. Education curricula that cannot adapt to social, cultural and community development, the educational output will not

KTSP Transition Towards 2013 Curriculum at Junior High School of Taman Dewasa Ibu Pawiyatan Tamansiswa, have relevance to the needs of the community. This certainly has a negative impact on the survival of educational institutions in the future.

The 2013 curriculum is a learning design that is designed to develop the potential of learners, aimed at realizing a generation of Indonesian people who are dignified, civilized, cultured, characterized, have faith, and are devoted to God Almighty, having noble, healthy, knowledgeable, capable, creative, independent, become democratic citizens, and be responsible. With careful consideration in the end the Junior High School of Taman Dewasa Ibu Pawiyatan Tamansiswa, Yogyakarta decided to transition from an educational unit level curriculum (KTSP) to the 2013 curriculum. Facing the curriculum transition needed good curriculum management. According to (Wahyudin, 2014) curriculum management in schools is the main management substance. The basic principle of management is to strive for the learning process to run well, by measuring the achievement of goals by students and encouraging teachers to develop and continuously refine their learning strategies. (Rusman, 2011) added that curriculum management is a curriculum management system that is cooperative, comprehensive, systemic, and systematic in order to realize the achievement of the curriculum goals. Speaking of curriculum management, then we need to formulate the scope of curriculum management which itself includes: planning, implementation, and evaluation. As said by (Triwiyanto, 2015) that curriculum management has three important aspects, namely with regard to how curriculum design (planning), curriculum implementation (implementation) and curriculum control (evaluation) by whom, where and in which scope.

Planning is the initial process of management to decide the goals and how to achieve them. Without curriculum planning it will be difficult to achieve the objectives of the curriculum itself. That is the reason why curriculum 
planning is needed. Planning is a strategic factor in implementing a curriculum, especially in a new curriculum. Many factors must be prepared so that the implementation works well. Implementation planning is important as a frame of reference so that efficiency occurs in the utilization of all resources, both infrastructure and human resources. Planning can be an important instrument for program evaluation to what extent the curriculum implementation goals and objectives can be achieved. (Katuuk, 2014). (Nasbi, 2018) argues that the intention of management in curriculum planning is the skill of "managing" in the sense of the ability to plan and organize the curriculum. The things that need to be considered in the curriculum planning process are who is responsible for curriculum planning, and how the curriculum planning is professionally planned.

Curriculum planning in Junior High School of Taman Dewasa Ibu Pawiyatan Tamansiswa, Yogyakarta is carried out by involving all relevant stakeholders including the principal, deputy head of curriculum, deputy head of student affairs, deputy head of facilities and infrastructure, teacher team and school committee (community). All aspects are taken care of in order to get conformity with the vision and mission of the school without losing the values that are characteristic of Junior High School of Taman Dewasa Ibu Pawiyatan Tamansiswa, Yogyakarta such as emphasizing the arts and culture and character.

The general curriculum planning principles are as follows:

1. Planning curriculum in accordance with the interests of students.

2. Curriculum planning is based on various decisions about content and processes.

3. Curriculum planning involves many groups.

4. Curriculum planning contains decisions on various issues and topics.
5. Curriculum planning is carried out at various levels.

6. Curriculum planning is an ongoing process.

Aspects that characterize curriculum planning include:

1. Curriculum planning must be based on clear concepts of various things that make life better for present and future society, and basic human needs.

2. Curriculum planning must be made in a comprehensive framework, which considers and coordinates the essential elements of effective teaching and learning.

3. Curriculum planning must be reactive and anticipatory. Education must be responsive to the needs of students, to help students lead a good life for the present and the future.

4. Educational objectives must cover a wide range of needs and interests regarding individuals and society.

5. The formulation of various objectives of the approach must be clarified with concrete illustrations, so that they can be used in the development of specific curriculum plans. if not, the perception that arises is less clear and contradictory.

6. In curriculum planning, a continuous evaluation must be carried out on all aspects of curriculum decision making, which also includes an analysis of the curriculum process and content.

The principles of curriculum planning are also considered, namely objectivity, cohesiveness, benefits, efficiency and effectiveness, compatibility, balance, ease, sustainability, standardization, and quality. In addition, the relevance of curriculum planning is carried out in such a way that schools can package the suitability of the curriculum and the vision and mission of the school to support one another. In addition to the agreed meetings, it is not 
uncommon for schools to also invite speakers from outside the school as a form of seriousness and socialization in order to succeed the 2013 curriculum planning, at least inviting school supervisors to hold workshops, seminars, and trainings. (Mulyasa, 2013) explained that socialization in curriculum implementation is very important, so that all parties involved in implementing it in the field understand the changes that must be made in accordance with their main tasks and functions, so that they provide support for the changes made.

The implementation of the curriculum is a process that is intended to realize practical actions that can provide benefits or impacts in the form of change, knowledge, skills, values and attitudes. The implementation of the curriculum is part of the program to improve the quality of education through the application of the management pattern of national curriculum implementation. This is done in an effort to achieve previously determined competencies in curriculum planning. Curriculum planning that has been prepared as it should be carried out the implementation of the plan because no matter how great the curriculum planning, there will be no meaningful meaning if there is no curriculum implementation.

(Hamalik, 2010) explained earlier that curriculum implementation was divided into two, namely the implementation of the school level and the implementation of the class level. The following is an explanation: at the school level, the principal is responsible for implementing the curriculum in the school environment he leads. The principal is obliged to carry out activities that are compiling an annual plan, compiling an activity implementation schedule, chairing meetings and making minutes of the meeting, making statistics and preparing reports. Whereas implementation at the class level, the teachers responsible for ensure the smooth implementation of the curriculum of the classroom environment, the division of tasks in the form of three types of administrative activities as follows: division of teaching assignments, division of extracurricular coaching tasks, and division of tutoring tasks.

The Junior High School of Taman Dewasa Ibu Pawiyatan Tamansiswa, Yogyakarta applies both curriculums, namely the 2013 curriculum intended for grades 7 and 8, while the 2006 curriculum or KTSP is intended for grade 9. In implementing education in schools there are three main activities, namely intracuricular activities, curricular activities and extracurricular. The three activities are an integrated whole that is inseparable in the effort to achieve the overall educational goals in an education/school unit. In addition, the three activities also reflect the outline of curriculum implementation as follows:

1. Intracurricular activities are the main activities of the school which are carried out using the time allocation specified in the program structure. This activity is carried out by the teacher and students in lesson hours every day. This intracuricular activity is carried out to achieve the minimum objectives of each subject/field of study that is classified as core or specific. In Junior High School of Taman Dewasa Ibu Pawiyatan Tamansiswa, Yogyakarta, the intrakulikuler activities went hand in hand with adjustments to the curriculum's implementation. Each curriculum is adapted to subject matter that has been prepared in such a way without leaving additional student subject matter as a specialty of Junior High School of Taman Dewasa Ibu Pawiyatan Tamansiswa, Yogyakarta itself that breathes culture and culture and manners and noble values such as student life.

2. Co-curricular activities are activities that are intended to deepen and appreciate the subject matter that has been learned in intracuricular activities in the classroom. This activity can be done individually or in groups. This is necessary to avoid repetition and overlapping between one subject and another. In addition, it also needs to be maintained so that students do not "overdose" because all teachers give assignments at the same time, so students bear a very heavy burden. Co-curricular activities KTSP Transition Towards 2013 Curriculum at Junior High School of Taman Dewasa Ibu Pawiyatan Tamansiswa, 
are activities directly related to intracuricular activities. The goal, to provide opportunities for students to explore and appreciate the subject matter. This co-curricular activity is carried out in addition to not causing excessive burdens for students as well as for the burden of parental expenses such as paying extra tutoring from outside school also can be overcome. The co-curricular activities are carried out with a regular system of administration, monitoring and assessment. In Junior High School of Taman Dewasa Ibu Pawiyatan Tamansisw itself, the co-curricular activities were carried out to facilitate students who were assessed as needing co-curricular activities, such as specifically for grade 9 there were material deepening tests (MDT) the form of tryouts conducted from Junior High School of Taman Dewasa Ibu Pawiyatan Tamansiswa it was done twice every year. In addition to the MDT, there were also additional lessons from the subject teachers before the national examination which was considered necessary to do. So far the school continues to provide assistance in the implementation of the cocurricular activities so that students can master the subject matter well and graduate with satisfactory achievements.

3. Extracurricular activities are intended as activities directed for broadening student knowledge, developing values or attitudes and further applying the knowledge students have learned from intracurricular and co-curricular activities. Although is carried out outside class hours, when compared to co-curricular activities, that extracurricular activities place more emphasis on group activities. Extracurricular activities are carried out by paying attention to students' interests and talents, as well as environmental and sociocultural conditions. The implementation of extracurricular activities is handled by the teacher or other designated officer. Extracurricular activities are filled with sports activities such as basketball, volleyball, martial arts, and the arts activities such as drama, painting, dance and so on. The whole field is intended for facilitate students to develop themselves, building students' identities, values, positive attitudes. In Junior High School of Taman Dewasa Ibu Pawiyatan Tamansiswa students have favorite extracurricular that is volleyball, painting and futsal which have the most interest each year than other fields.

The implementation of the curriculum in Junior High School of Taman Dewasa Ibu Pawiyatan Tamansiswa can be said to run smoothly and can meet the stipulated conditions as contained in the school curriculum planning. The implementation is done in stages by applying the two existing curriculum, namely the 2013 curriculum intended for grades 7 and 8 , while the 2006 curriculum or KTSP is intended for grade 9 . School policies through socialization including workshops, seminars and training that can support the curriculum implementation process also went well with the presence of speakers at least the school supervisors who are usually conducted at the beginning of the learning year. So that there are no problems that are still worrying about the implementation of the curriculum both in the learning process in the classroom and at school such as how the curriculum is implemented, what administration must be met, and so on, including minimizing the difficulties of students in implementing the curriculum.

At this time there are no obstacles or difficulties both from teachers and students in the implementation of the curriculum due to the maximization of socialization policies and good cooperation among stakeholders. This is reinforced by (Husnawati, 2013) related to alternative problem solving regarding the preparation of learning devices has been overcome by the existence of joint learning device preparation activities carried out at the beginning of learning and holding workshops related to the making of learning devices. If the teacher experiences problems in implementing the 2013 curriculum, the teacher submits to the principal to find a solution to the problem faced by the teacher, then the principal requests assistance from the school supervisor to find a solution to the problem faced by the teacher. In addition, teachers can also share with fellow 
teachers who implement the 2013 curriculum and teachers who are not implementing the 2013 curriculum.

Curriculum evaluation is very important because curriculum evaluation can provide information about the suitability, effectiveness, and efficiency of the curriculum to the objectives to be achieved and the use of resources, which information is very useful as material for decision makers whether the curriculum is still running, needs revision, should replaced or not used anymore. Curriculum evaluations In Junior High School of Taman Dewasa Ibu Pawiyatan Tamansiswa have two categories of evaluation evaluations conducted from internal schools and those from external schools. Assessments originating from internal schools are the principal, deputy head of curriculum, deputy head of student affairs, deputy head of facilities and infrastructure, and the teacher team. while assessments originating from external schools are school supervisors, the community, and school committees. Assessment is carried out in the semester which consists of mid-semester assessment and endsemester assessment. With educational calendar tools that have been described in detail in conducting evaluations through predetermined meetings. Why do schools consider the need to carry out curriculum evaluation policies. Because the school assesses the holding of the curriculum evaluation, the school can find out the results and follow up in the future whether the curriculum is feasible to be maintained or needs to be replaced or even eliminated.

Meanwhile, according to (Ningrum, Sulistya, Sobri, \& Yusuf, 2015) evaluation in curriculum implementation is needed by schools so that the government knows the obstacles experienced by teachers and principals in implementing the curriculum because of each school the obstacles faced are different. From the results of the curriculum evaluation meeting that was implemented In Junior High School of Taman Dewasa Ibu Pawiyatan Tamansiswa, the curriculum was considered able to meet the needs of students. In the near future the Junior
High School of Taman Dewasa Ibu Pawiyatan Tamansiswa plans to implement the 2013 curriculum as a whole in each class.

\section{CONCLUSION/RECOMENDATION}

The curriculum is a tool for achieving teaching and education goals. The curriculum is the basis for implementing education. There are three systematic stages to achieving success in an educational curriculum, namely curriculum planning, curriculum implementation, and curriculum evaluation. The Junior High School of Taman Dewasa Ibu Pawiyatan Tamansiswa has conducted three systematic stages in the process of implementing the 2013 curriculum transition with good results which can adjust the curriculum to the conditions of the school's needs and still maintain the school's identity which breathes the values of art and culture and character. The 2013 curriculum was implemented by involving all stakeholders concerned in stages intended for classes 7 and 8, while for class 9 still using the 2006 curriculum or KTSP. In the future the Junior High School of Taman Dewasa Ibu Pawiyatan Tamansiswa plans to implement the 2013 curriculum as a whole until grade 9 .

\section{REFERENCES}

Answar, R. (2014). Hal-Hal yang Mendasari Penerapan Kurikulum 2013. Binus University: Journal Humaniora, 97-106 Vol. 5 No. 1.

Cresswell, J. (2015). Riset Pendidikan: Perencanaan, Pelaksanaan, dan Evaluasi: Riset Kualitatif \& Kuantitatif. Edisi 5. Pustaka Pelajar: Pearson education. Inc. Terjemahan Helly Prajitno Soetjipto.

Hakim, D. (2014). Implementasi Pendidikan Budaya dan Karakter Bangsa dalam Kurikulum Tingkat Satuan Pendidikan (KTSP) Di Sekolah. Religi: Jurnal Studi Islam, 145-168 Vol. 5 No. 2 ISSN: 1978-306X

Hamalik, O. (2010). Manajemen Pengembangan Kurikulum. Cet. IV. Bandung: PT. Remaja Rosdakarya.

Hidayat, S. (2013). Pengembangan Kurikulum Baru. Bandung: Remaja Rosdakarya.

Husnawati, Z. (2013). Implementasi kurikulum tingkat satuan pendidikan (KTSP) di sekolah dasar islam (SDI) . Malang: surya buana malang. FIP UM.

Katuuk, D. A. (2014). Manajemen Implementasi Kurikulum: Strategi Penguatan Implementasi Kurikulum 2013. Cakrawala Pendidikan, 17. 
Kurniasih, I., \& Sani, B. (2014). Implementasi Kurikulum 2013 Konsep \& Penerapan. Surabaya: Kata Pena.

Lazwardi, D. (2017). Manajemen Kurikulum sebagai Pengembangan Tujuan Pendidikan. Al-Idarah: Jurnal Kependidikan Islam, Vol. 7 No. 1.

Machali, I. (2014). Kebijakan Perubahan Kurikulum 2013 dalam Menyongsong Indonesia Emas Tahun 2024. Jurnal Pendidikan Islam, 71-94. Vol. IIII No. 1. DOI. 10. 14421/Jpi.2014.31.

Miles, M. B., Huberman, A. M., \& Saldana, J. (2014). Qualitative Data Analysis, A Methods Sourcebook, Edition 3. USA: Sage Publications. Terjemahan Tjetjep Rohindi Rohidi, UI-Press.

Mulyasa, E. (2013). Pengembangan dan Implementasi Kurikulum. Bandung: PT. Remaja Rosdakarya.

Nasbi, I. (2018). Manajemen Kurikulum: Sebuah Kajian Teoritis. Jurnal Idaarah, Vol. 1 No. 2.

Ningrum, Sulistya, E., Sobri, \& Yusuf, A. (2015). Implementasi Kurikulum 2013 di Sekolah Dasar. Manajemen Pendidikan. 416-423 Vol. 24 No. 5.

Pawero, A. M. (2018). Analisis Kritis Kebijakan Kurikulum antara KBK, KTSP, dan K-13. Iqro' Fakultas Tarbiyah dan Ilmu Keguruan IAIN Manado, Vol. 12, No. 1.

Prastowo, A. (2018). Transformasi Kurikulum Pendidikan Dasar Dan Menengah Di Indonesia (Kurikulum Tingkat Satuan Pendidikan Menuju
Kurikulum 2013 Hingga Kurikulum Ganda). Jurnal Ilmiah PGMI, Vol. 4 No. 2.

Rusman. (2011). Manajemen Kurikulum. Jakarta: PT Raja Grafindo Persada.

Sugiyono. (2015). Metode Penelitian Kuantitatif Kualitatif dan $R \& D$. Bandung: Alfabeta.

Tilaar, H. (2012). Perubahan Sosial dan Pendidikan. Jakarta: Rineka Cipta.

Trisnawati, D. (2016). Perbandingan Implementasi Kurikulum Tingkat Satuan Pendidikan (KTSP) dan Kurikulum 2013 di SMAN 1 Sinjai Utara. Jurnal Mirai Management, Vol. 1 No.1.

Triwiyanto, T. (2015). Manajemen Kurikulum dan Pembelajaran. Jakarta: Bumi Aksara.

Uran, L. L. (2018). Evaluasi Implementasi KTSP dan Kurikulum 2013 pada SMK Se-Kabupaten Belu, Nusa Tenggara Timur. Jurnal Penelitian dan Evaluasi Pendidikan, Vol. 22 No. 2018 DOI. http://dx.doi.org/10.21831/pep.v22i1.1330.

Wahyudin, D. (2014). Manajemen Kurikulum. Bandung: PT Remajarosda Karya.

Wangid, M. N., \& Dkk. (2018). Kesiapan Guru SD dalam Pelaksanaan Pembelajaran TematikIntegratif pada Kurikulum 2013 di DIY. Jurnal Prima Edukasia, Vol. 2 No. 2. 